\title{
PENGARUH PEMBELAJARAN MODEL KOOPERATIF TIPE JIGSAW DAN TPS TERHADAP KEMAMPUAN BERPIKIR KREATIF SISWA KELAS $X$ SMAN 1 DRIYOREJO
}

\author{
Tutik Andayani \\ STKIP Bina Insan Mandiri, Email: uchiez2503@gmail.com
}

\begin{abstract}
Abstrak
Berpikir kreatif merupakan hal yang penting dalam pembelajaran matematika. Banyak guru matematika belum mengembangkan kemampuan ini. Dengan menerapkan model pembelajaran kooperatif, guru mampu meningkatkan kemampuan berpikir kreatif siswa. Penelitian ini bertujuan untuk mendeskripsikan pengaruh pembelajaran model kooperatif tipe Jigsaw dan tipe TPS terhadap kemampuan berpikir kreatif siswa kelas X SMAN 1 Driyorejo dan mendeskripsikan kemampuan berpikir kreatif siswa antara: a) pembelajaran model kooperatif tipe TPS dengan model Konvensional, b) pembelajaran model kooperatif tipe Jigsaw dengan TPS, dan c) pembelajaran model kooperatif tipe Jigsaw dengan model Konvensional pada kelas X SMAN 1 Driyorejo. Metode penelitian ini adalah penelitian kuantitatif dengan desain penelitian pretest-posttest control group. Sampel penelitian berjumlah 108 siswa terdiri dari 36 siswa kelas eksperimen (Jigsaw), 36 siswa kelas eksperimen (TPS), dan 36 siswa kelas kontrol (Konvensional) yang diperoleh dengan teknik random sampling. Instrumen pengumpulan data menggunakan tes dan teknik analisis data menggunakan analisis inferensial. Hasil penelitian menunjukkan bahwa baik pada pembelajaran model kooperatif tipe Jigsaw maupun model kooperatif tipe TPS berpengaruh terhadap kemampuan berpikir kreatif siswa kelas X SMAN 1 Driyorejo. Kemampuan berpikir kreatif siswa pada pembelajaran model koopertaif tipe Jigsaw dan TPS berada pada kategori cukup kreatif, sedangkan model konvensional berada pada kategori kurang kreatif.
\end{abstract}

Kata Kunci: Berpikir Kreatif, Model Pembelajaran Kooperatif Tipe Jigsaw, dan Model Pembelajaran Kooperatif Tipe TPS

\begin{abstract}
Abstrak
Creative thinking is crucial in learning mathematics. Many teachers of mathematics have not developed this ability. By applying a model of cooperative learning, teachers are able to improve students creative thinking skills. This study aims to describe the influence of cooperative learning model type and type of TPS Jigsaw against the ability of creative thinking of students of class X SMAN 1 Driyorejo and describe the ability of the creative thinking of students between: a) the learning model cooperative type TPS with a Conventional model, b) learning model cooperative type of Jigsaw with TPS, and c) learning model cooperative type of Jigsaw with a Conventional model on a class X SMAN 1 Driyorejo. The method of this research is the study of quantitative experiments with
\end{abstract}


pretest-posttest design research control group. Sample research amounted to 108 students consists of 36 students class experiments (Jigsaw), 36 students class experiments (TPS), and 36 grade-control (Konvensional) obtained by random sampling techniques. Data collection instruments using tests and data analysis techniques using inferensial analysis. The results showed that good at learning model cooperative type Jigsaw nor the TPS effect on creative thinking ability of students of class X SMAN 1 Driyorejo. The ability of the creative thinking of students in learning model koopertaif type of Jigsaw and TPS are in the category of creative enough, while the conventional model is on the category less creative.

Keywords: Creative Thinking, Cooperative Learning Jigsaw-Type Models, and Models of Cooperative Learning Type of TPS

\section{PENDAHULUAN}

Perkembangan teknologi dan informasi saat ini tidak dapat dipungkiri merupakan hasil dari kemampuan berpikir kreatif manusia. Upaya meningkatkan kemampuan berpikir kreatif dalam menghadapi tantangan serta perubahan-perubahan teknologi di masa depan, adalah melalui pendidikan yang berkualitas. Semua bidang pendidikan tak terkecuali pendidikan matematika wajib memulai dan memusatkan pada tujuan tersebut (Siswono, 2018:1). Berdasarkan observasi yang peneliti lakukan pada SMAN 1 Driyorejo dan wawancara dengan guru kelas $\mathrm{X}$, didapatkan informasi bahwa pembelajaran matematika pada umumnya masih berlangsung secara tradisional dengan pendekatan ekspositori. Selama ini guru hanya menerapkan dua model

pembelajaran kooperatif, yaitu model kooperatif tipe Student TeamsAchievement Division (STAD) dan Team Games-Tournament (TGT). Disamping itu, soal latihan yang diberikan lebih banyak menggunakan soal rutin sehingga kurang melatih kemampuan berpikir kreatif dan daya nalar siswa dalam pemecahan masalah. Oleh karena itu diperlukan upaya-upaya untuk pembenahan terhadap pembelajaran matematika dalam rangka melatih kemampuan berpikir kreatif siswa. Salah satunya adalah penerapan pembelajaran kooperatif. Banyak macam kegiatan belajar kooperatif dengan pendekatan kolaboratif, beberapa diantaranya Cooperative Script, Think Pair Share, Pair Check, Role Playing, Two-Stay Two-Stray, Number Heads Together, Student Teams-Achievement Division, 
Team Games-Tournament dan Jigsaw (Huda, 2013:197).

Jigsaw dan Think Pair Share (TPS) merupakan salah satu model pembelajaran kooperatif yang dirancang untuk mempengaruhi pola interaksi siswa serta meningkatkan rasa tanggung jawab siswa terhadap pembelajarannya sendiri dan juga pembelajaran orang lain. Sehingga ide yang muncul lebih banyak dan beragam. Andriyani, dkk (2013:652) mengatakan bahwa model kooperatif tipe Jigsaw, menuntut siswa untuk bekerjasama saling ketergantungan positif dan bertanggung jawab secara mandiri dalam memahami suatu materi. Karena peran siswa dalam kelompok ahli bertugas menjelaskan kembali materi pada kelompok asal mereka. Sedangkan pada pembelajaran dengan model kooperatif tipe TPS, siswa dituntut untuk berpikir dan saling bekerjasama satu sama lain secara individu (Think), berpasangan (Pair), dan berbagi (Share). Husna, dkk (2013:83) mengatakan model koooperatif tipe TPS merupakan suatu cara efektif untuk membuat variasi suasana pola diskusi siswa, dengan asumsi bahwa semua diskusi membutuhkan peraturan untuk mengendalikan kelas secara keseluruhan.

Nur dan Abdullah (2014:39) dalam penelitiannya menyimpulkan bahwa kemampuan berpikir kreatif matematis siswa pada pembelajaran dengan model kooperatif tipe Jigsaw lebih baik dari pada pembelajaran konvensional. Natalliasari (2013:103) dalam penelitiannya menyimpulkan bahwa pembelajaran dengan model kooperatif tipe TPS mampu meningkatkan kemampuan pemecahan masalah dan penalaran siswa. Meskipun pada peneltian ini tidak ditinjau dari kemampuan berpikir kreatif siswa, tetapi penelitian ini masih relevan karena kreativitas dan keterampilan kognitif siswa dapat dikembangkan melalui kemampuan memecahkan masalah dan penalaran siswa (Pehkonen, 1997). Dimana Kreativitas sendiri merupakan produk dari berpikir kreatif seseorang (Siswono, 2004:78).

Dipandang sebagai produk, Silver (dalam Siswono, 2018:121) menguraikan bahwa berpikir kreatif menekankan pada tiga komponen kunci menggunakan The Torrance Tests of Creative Thinking (TTCT) yaitu pada aspek kefasihan (fluency), keluwesan 
(flexibility), dan kebaruan (Novelty). Kelancaran dapat diidentifikasi dari banyaknya solusi dengan jawaban beragam dan benar yang didapat siswa. Keluwesan dapat diidentifikasi dari banyaknya metode atau cara yang digunakan siswa. Sedangkan dikatakan kebaruan jika unik atau menemukan solusi tidak umum pada siswa di kelas. Permasalahan open-ended adalah suatu masalah yang mendorong kemampuan berpikir kreatif siswa. Suherman (dalam Fardah, 2012) menyatakan bahwa permasalahan open-ended adalah sebuah permasalahan yang mempunyai banyak jawaban benar digunakan untuk mengukur tingkat kemampuan berpikir kreatif siswa (Putri dan Wijayanti, 2013). Hal tersebut sejalan dengan indikator kemampuan berpikir kreatif TTCT.

Dari latar belakang di atas yang menjadi masalah dalm penelitian adalah: 1) Apakah pembelajaran model kooperatif tipe Jigsaw, TPS, dan model konvensional berpengaruh terhadap kemampuan berpikir kreatif siswa kelas X SMAN 1 Driyorejo?, 2) Bagaimana kemampuan berpikir kreatif siswa antara: a) Pembelajaran model kooperatif tipe TPS dengan model
Konvensional, b) Pembelajaran model kooperatif tipe Jigsaw dengan TPS, dan c) Pembelajaran model kooperatif tipe Jigsaw dengan model Konvensional pada kelas X SMAN 1 Driyorejo?.

Sesuai dengan rumusan masalah tersebut maka tujuan penelitian ini adalah untuk mendeskripsikan: 1) Pengaruh pembelajaran model kooperatif tipe Jigsaw, TPS, dan model Konvensional terhadap kemampuan berpikir kreatif siswa kelas X SMAN 1 Driyorejo, 2) Kemampuan berpikir kreatif siswa antara: a) Pembelajaran model kooperatif tipe TPS dengan model Konvensional, b) Pembelajaran model kooperatif tipe Jigsaw dengan TPS, dan c) Pembelajaran model kooperatif tipe Jigsaw dengan model Konvensional pada kelas X SMAN 1 Driyorejo.

Penelitian ini menggunakan metode penelitian eksperimen dengan pendekatan kuantitatif Populasi dalam peneltian ini adalah seluruh siswa kelas $\mathrm{X}$ SMAN 1 Driyorejo tahun ajaran 2018/2019. Sampel penelitian adalah siswa kelas X-IPA 3 sebagai kelas eksperimen Jigsaw sebanyak 36 siswa, kelas X-IPA 4 sebagai kelas eksperimen TPS sebanyak 36 siswa, dan kelas X-IPA 5 sebagai kelas kontrol sebanyak 36 
siswa. Teknik pengambilan sampel yang digunakan adalah teknik random sederhana yang dilakukan dengan undian. Desain penelitian ini menggunakan pretest-posttest control group design berikut ini.

\begin{tabular}{|lllll|}
\hline $\mathrm{E}$ & $:$ & $\mathrm{O}_{1}$ & $\mathrm{X}_{1}$ & $\mathrm{O}_{2}$ \\
$\mathrm{E}$ & $:$ & $\mathrm{O}_{1}$ & $\mathrm{X}_{2}$ & $\mathrm{O}_{2}$ \\
$\mathrm{~K}$ & $:$ & $\mathrm{O}_{1}$ & & $\mathrm{O}_{2}$ \\
\hline
\end{tabular}

(Azwar, 2010:118).

Keterangan:

$\mathrm{E} \quad=$ Kelas eksperimen

$\mathrm{K}=$ kelas kontrol

$\mathrm{O}_{1}=$ Pretest kelas eksperimen dan kelas kontrol

$\mathrm{O}_{2}=$ Posttest kelas eksperimen dan kelas kontrol

$\mathrm{X}_{1}=$ Perlakuan menggunakan model pembelajaran kooperatif tipe Jigsaw

$\mathrm{X}_{2}=$ Perlakuan menggunakan model pembelajaran kooperatif tipe TPS.

Teknik pengumpulan data dalam penelitian ini dilakukan melalui observasi, wawancara dan tes, yaitu pretest dan posttest. Instrumen tes berupa 3 soal uraian berbasis openended mengacu pada konsep kemampuan berpikir kreatif siswa yang memiliki indikator fluency, flexibility dan novelty.

Sebelum penelitian dilaksanakan, ketiga kelas harus dalam keadaan seimbang. Maka perlu dilakukan uji kesamaan rata-rata, yaitu menggunakan uji One Way Analisis of Variance (ANOVA) dengan taraf signifikansi 0,05. Sedangkan untuk mengetahui kesamaan rata-rata pada dua sampel yang berpasangan menggunakan uji Paired Sample $T$ Test dengan taraf signifikansi 0,05 .

\section{HASIL DAN PEMBEHASAN}

Hasil kemampuan berpikir kreatif siswa pada kelas eksperimen dan kelas kontrol disajikan dalam Tabel 1 berikut.

Tabel 1. Data Hasil Kemampuan Berpikir Kreatif Siswa

Kelas Eksperimen dan Kelas Kontrol

\begin{tabular}{ccc}
\hline Kelas & $\begin{array}{c}\text { Hasil } \\
\text { Pretest }\end{array}$ & $\begin{array}{c}\text { Hasil } \\
\text { Posttest }\end{array}$ \\
\hline $\begin{array}{c}\text { Eksperimen } \\
\text { (Jigsaw) }\end{array}$ & 45,19 & 55,08 \\
\hline $\begin{array}{c}\text { Eksperimen } \\
\text { (TPS) }\end{array}$ & 43,81 & 47,03 \\
\hline Kontrol & 44,03 & 45,64 \\
\hline
\end{tabular}

Tabel 1 menunjukkan bahwa nilai rata-rata pada kelas eksperimen Jigsaw mengalami kenaikan sebesar 9,89 atau $21,88 \%$. Nilai rata-rata pada kelas eksperimen TPS mengalami kenaikan sebesar 3,22 atau 7,35\%. Sedangkan 
nilai rata-rata pada kelas kontrol mengalami kenaikan sebesar 1,61 atau $3,66 \%$. Sehingga dari penelitian ini terungkap bahwa pembelajaran model kooperatif tipe Jigsaw mempengaruhi kemampuan berpikir kreatif siswa lebih tinggi apabila dibandingkan dengan pembelajaran model kooperatif tipe TPS dan model konvensional.

Hasil perhitungan uji one way ANOVA kesamaan rata-rata data pretest ketiga kelas dapat dilihat pada Tabel 2 berikut ini.

Tabel 2. Kesamaan Rata-Rata Hasil Pretest Siswa Tukey HSD ${ }^{\mathrm{a}}$

\begin{tabular}{ccc}
\hline Hasil & N & $\begin{array}{c}\text { Subset for } \\
\text { alpha }= \\
\mathbf{0 , 0 5}\end{array}$ \\
\cline { 2 - 3 } & & 1 \\
\hline Pretest TPS & 36 & 43,81 \\
\hline $\begin{array}{c}\text { Pretest } \\
\text { Konvensional }\end{array}$ & 36 & 44,03 \\
\hline Prestes Jigsaw & 36 & 45,19 \\
\hline Sig. & &, 940 \\
\hline
\end{tabular}

Subset 1 pada Tabel 2 di atas terdapat pretest Jigsaw, TPS dan Konvensional. Artinya tidak ada perbedaan rata-rata yang signifikan pada kemampuan awal siswa atau nilai ratarata kemampuan awal siswa adalah sama.

Tabel 3. Uji Paired Sample T Test 
sebesar 0,001 < 0,025 maka $\mathrm{H}_{0}$ ditolak, $\mathrm{H}_{\mathrm{a}}$ diterima. Artinya pembelajaran model kooperatif tipe TPS berpengaruh terhadap kemampuan berpikir kreatif siswa. hal tersebut sejalan dengan penelitian Husna, dkk (2013:90) bahwa terjadi peningkatan kemampuan pemecahan masalah dan komunikasi matematis siswa yang pembelajaran model kooperatif tipe TPS dari pada siswa yang memperoleh pembelajaran konvensional. Sedangkan nilai Sedangkan nilai Sig. (2-tailed) pada pair 3 sebesar 0,052>0,025 yang artinya pembelajaran konvensional tidak berpengaruh terhadap kemampuan berpikir kreatif siswa.

Sedangkan hasil perbandingan ketiga kelas perindikator ditunjukkan pada Tabel 4 berikut.

Tabel 4. Perbandingan Nilai Kemampuan Berpikir Kreatif Siswa

\begin{tabular}{|c|c|c|c|c|c|c|c|c|}
\hline \multirow[b]{2}{*}{ No. } & \multirow[b]{2}{*}{$\begin{array}{l}\text { Indi } \\
\text { kator }\end{array}$} & \multirow{2}{*}{$\begin{array}{c}\mathrm{Ni} \\
\text { lai } \\
\mathrm{M} \\
\text { ak } \\
\mathrm{S}\end{array}$} & \multicolumn{2}{|c|}{ Jigsaw } & \multicolumn{2}{|c|}{ TPS } & \multicolumn{2}{|c|}{ Kontrol } \\
\hline & & & $\bar{x}$ & $\%$ & $\bar{x}$ & $\%$ & $\bar{x}$ & $\%$ \\
\hline 1 & Fluency & 4 & $\begin{array}{l}2 \\
00\end{array}$ & $\begin{array}{l}50,0 \\
0\end{array}$ & $\begin{array}{l}1, \\
58\end{array}$ & $\begin{array}{l}39 \\
, 5 \\
8\end{array}$ & $\begin{array}{l}1, \\
69\end{array}$ & $\begin{array}{c}42 \\
3 \\
6\end{array}$ \\
\hline 2 & Novelty & 4 & $\begin{array}{l}2, \\
28\end{array}$ & $\begin{array}{l}56,9 \\
4\end{array}$ & $\begin{array}{l}1, \\
92\end{array}$ & $\begin{array}{l}47 \\
9 \\
2\end{array}$ & $\begin{array}{l}1, \\
82\end{array}$ & $\begin{array}{l}45 \\
1 \\
4\end{array}$ \\
\hline 3 & $\begin{array}{l}\text { Flexibilit } \\
y\end{array}$ & 4 & $\begin{array}{l}2, \\
33\end{array}$ & $\begin{array}{l}58,8 \\
3\end{array}$ & $\begin{array}{l}2, \\
14\end{array}$ & $\begin{array}{l}53 \\
4 \\
7\end{array}$ & $\begin{array}{l}1, \\
97\end{array}$ & $\begin{array}{c}49 \\
3 \\
1\end{array}$ \\
\hline
\end{tabular}

Keterangan : $\bar{x} \quad$ : Rata-rata indikator berpikir kreatif

$\%$ : Persentase indikator berpikir kreatif

Tabel 5. Penjejangan Kemampuan Berpikir Kreatif Siswa

\begin{tabular}{llr}
\hline Tingkat & \multicolumn{2}{c}{ Nilai } \\
\hline Tingkat & Siswa mampu \\
4 & menunjukkan \\
(Sangat & kelancaran, fleksibilitas, \\
Kreatif) & dan kebaruan dalam \\
& memecahkan masalah \\
& Siswa mampu \\
Tingkat & menunjukkan kelancaran \\
3 & dan kebaruan atau \\
(Kreatif) & kefasihan deksibilitas dan \\
& memecahkan masalah \\
Tingkat & Siswa mampu \\
2 & menunjukkan kebaruan \\
(Cukup & atau fleksibilitas dalam \\
Kreatif) & memecahkan masalah \\
Tingkat & Siswa mampu \\
1 & menunjukkan kelancaran \\
(Kurang & dalam memecahkan \\
Kreatif) & masalah m \\
Tingkat & Siswa tidak mampu \\
0 & menunjukkan ketiga \\
(Tidak & aspek indikator berpikir \\
Kreatif) & kreatif. \\
\hline
\end{tabular}

Analisis perbandingan ketiga kelas perindikator pada Tabel 4 menunjukkan bahwa dari ketiga indikator kemampuan berpikir kreatif siswa, indikator flexibility terlihat paling tinggi baik di kelas eksperimen Jigsaw, eksperimen TPS, maupun kelas kontrol dibandingkan indikator yang lain. Berdasarkan penjejangan kemampuan berpikir kreatif siswa seperti pada Tabel 5 didapatkan bahwa kelas eksperimen 
dengan model kooperatif tipe Jigsaw termasuk dalam tingkatan 2 (cukup kreatif), hal tersebut didapat dari persentase indikator berpikir kreatif pada novelty sebesar $56,94 \%$ dan flexibility sebesar $58,83 \%$ dalam memecahkan masalah. Pembelajaran pada kelas eksperimen TPS berada dalam tingkatan 2 atau kategori cukup kreatif, hal tersebut dikarenakan pada kelas ini hanya mampu menunjukkan indikator flexibility dengan persentase 53,47\% dalam memecahkan masalah. Sedangkan pembelajaran pada kelas kontrol dalam tingkatan 0 atau kategori tidak kreatif, hal tersebut dikarenakan pada kelas ini tidak mampu menunjukkan ketiga aspek indikator berpikir kreatif.

Berdasarkan uaraian diatas dapat disimpulkan bahwa kemampuan berpikir kreatif siswa menggunakan model kooperatif tipe TPS (kategori cukup kreatif ) lebih baik dari pada model konvensional (kategori tidak kreatif). Hal tersebut sejalan dengan hasil peneltian Natalliasari (2013:103) dan Husna, dkk (2013:90) yang mengatakan bahwa, pembelajaran model kooperatif tipe TPS lebih baik dari pada konvensional. Serta pembelajaran model kooperatif tipe TPS dapat meningkatkan kemampuan penalaran serta komunikasi matematis siswa. Kemampuan berpikir kreatif siswa menggunakan model kooperatif tipe Jigsaw sama dengan model kooperatif tipe TPS, yakni dalam kategori cukup kreatif. Hal tersebut disebabkan pada kenyataan di lapangan, bahwa siswa masih bergantung negatif dengan kelompoknya. Yeni, dkk (2015) dan Natalliasari (2013) mengatakan bahwa setiap siswa saling bergantung pada teman satu kelompoknya untuk bisa mendapatkan informasi yang dibutuhkan pada saat penilaian baik pada model pembelajaran kooperatif tipe Jigsaw maupun pembelajaran model kooperatif tipe TPS.

Sedangkan kemampuan berpikir kreatif siswa menggunakan model kooperatif tipe Jigsaw (kategori cukup kreatif ) lebih baik dari pada model konvensional (kategori tidak kreatif). Hal tersebut sejalan dengan penelitian Nur dan Abdullah (2014:39) ; Yeni, dkk (2015) yang menyatakan bahwa pembelajaran model kooperatif tipe Jigsaw dapat mempengaruhi serta peningkatan kemampuan berpikir kreatif siswa dari pada pembelajaran konvensional, meskipun dalam kategori sedang. Hal ini dikarenakan pada pembelajaran model 
kooperatif tipe Jigsaw lebih menitikberatkan kepada kerja kelompok serta memberi kesempatan siswa untuk mengemukakan pendapat serta meningkatkan kemampuan berkomunikasi (Shoimin, 2017:90).

\section{SIMPULAN}

Berdasarkan hasil penelitian yang diperoleh dapat disimpulkan bahwa pembelajaran dengan model kooperatif tipe Jigsaw dan tipe TPS berpengaruh terhadap kemampuan berpikir kreatif siswa kelas X SMAN 1 Driyorejo. Kemampuan berpikir kreatif siswa dengan menggunakan model kooperatif tipe TPS berada pada kategori cukup kreatif, sedangkan model Konvensional berada pada kategori tidak kreatif pada $\begin{array}{lllll}\text { kelas } & \mathrm{X} & \text { SMAN } & 1 & \text { Driyorejo. }\end{array}$ Kemampuan berpikir kreatif siswa dengan menggunakan model kooperatif tipe Jigsaw dan model kooperatif tipe TPS pada kelas X SMAN 1 Driyorejo adalah sama yaitu dalam kategori cukup kreatif. Sedangkan kemampuan berpikir kreatif siswa dengan menggunakan model kooperatif tipe Jigsaw berada pada kategori cukup kreatif, sedangkan model Konvensional berada pada kategori tidak kreatif pada kelas $\mathrm{X}$ SMAN 1 Driyorejo.

\section{DAFTAR PUSTAKA}

Andriani, D. G., Kusmayadi, T. A., dan Mardiyana. (2013). Eksperimentasi Model Pembelajaran Kooperatif Tipe Jigsaw dan Think Pair Share Ditinjau Dari Kecerdasan Emosional Siswa SMP Se-Kota Kediri Tahun Pelajaran 2012/2013. Jurnal Elektronik Pembelajaran Matematika Vol 1 (7): 651-660 Desember 2013. (online), (https://www.jurnal.fkip.uns.ac.id/i ndex.php/s2math/article/view/3537 , diakses pada 10 Juli 2019).

Azwar, S. (2010). Metode Penetilian. Yogyakarta: Pustaka Pelajar

Fardah, D.K. (2012). Analisis Proses dan Kemampuan Berpikir Kreatif Siswa dalam Matematika Melalui Tugas Open-Ended. Jurnal Kreano Vol. 3(2) Desember 2012. (online), (https://journal.unnes.ac.id/nju/ind ex.php/kreano/article/view/2616, diakses 15 Desember 2018).

Huda, M. (2013). Model-Model Pengajaran dan Pembelajaran: Isu-Isu Metodis dan Paradigmatis. Yogyakarta: Pustaka Pelajar.

Husna, Ikhsan, M., Fatimah, S. 2013. Peningkatan Kemampuan Pemecahan Masalah dan Komunikasi Matematis Siswa Sekolah Menengah Pertama Melalui Model Pembelajaran Kooperatif Tipe Think Pair Share (TPS). Jurnal Peluang Vol. 1(2) April 2013. (online), (https://www.jurnal.unsyiah.ac.id/p eluang/article/download/1061/997, diakses 2 Maret 2019).

Natalliasari, I. (2013). Penggunaan Model Pembelajaran Kooperatif 
Tipe Think Pair Share (TPS) Untuk Meningkatkan Kemampuan Penalaran dan Pemecahan Masalah Matematis Siswa MTs. Jakarta: Universitas Terbuka. Tesis tidak dipublikasikan.

Nur, I. M., dan Abdullah, I. H. (2014). Penggunaan Model Pembelajaran Kooperatif Tipe Jigsaw untuk Meningkatkan Kemampuan Berpikir Kreatif dan Soft Skill Matematis Siswa SMA. Delta-pi: Jurnal Matematika dan Pendidikan Matematika Vol. 3(2) Oktober 2014. (online), (https://www.ejournal.unkhair.ac.i d/index.php/deltapi/article/view/13 6, diakses 15 Desember 2018).

Pehkonen, E. (1997). The State of Art in Mathematical Creativity. ZDM International Reviews on Mathematical Education Articles. Electronic Edition. Vol. 29(3): 6364.

Putri, V. S. R., \& Wijayanti, P. (2013). Identifikasi Tingkat Kemampuan Berpikir Kreatif (TKBK) Siswa dalam Menyelesaikan Soal OpenEnded pada Materi Segiempat di Kelas VIII SMP. MATHEdunesa
Vol. 2(2). (online), (https://jurnalmahasiswa.unesa.ac.i d/index.php/mathedunesa/article/vi ew/2708, diakses 15 Desember 2018).

Siswono, T. Y. E. (2004). Mendorong Berpikir Kreatif Siswa Melalui Pengajuan Masalah (Problem Posing). Makalah dipresentasikan pada Konferensi Nasional Matematika XII, Universitas Udayana Denpasar, 23-27 Juli 2004.

Siswono, T. Y. E. (2018). Pembelajaran Matematika Berbasis Pengajuan dan Pemecahan Masalah. Bandung: PT. Remaja Rosdakarya.

Yeni, E., Hardianto, dan Suwandi. (2015). Pengaruh Model Pembelajaran Kooperatif Tipe Jigsaw Terhadap Hasil Belajar Matematika Siswa Kelas X SMA Negeri 3 Rambah Hilir. Jurnal Ilmiah Mahasiswa FKIP Prodi Matematika Vol. 1(1) Tahun 2015. (online), (http://ejournal.upp.ac.id/index.php/mtkfki p/article/view/256/261, diakses 20 Desember 2018. 